TELEMATIKA, Vol. 06, No. 02, JANUARI, 2010, Pp. 31 - 40

ISSN 1829-667X

\title{
SISTEM PAKAR MENGGUNAKAN MESIN INFERENSI FUZZY UNTUK MENENTUKAN HAMA DAN PENYAKIT PADA TANAMAN BAWANG MERAH
}

\author{
Wilis Kaswidjanti \\ Jurusan Teknik Informatika UPN "Veteran" Yogyakarta \\ e-mail : wilisk@yahoo.com
}

\begin{abstract}
This research is based on the needs of a tool which can help farmers in identifying of pests and disease in vegetables/palawija crop, and also controlling it in order to give the right peptiside. The tool is an expert system capable of not only diagnose, but also to give the operation suggestion. Basically this tool consists of 2 bodyworks, that is, a part for inputting knowledge bases, and a part for consultancy. The decision making is implemented in terms of production rules. The use of fuzzy inference method and the type of defuzzifier are max-min and center average respectively. Output from this tool is crop pest/disease type and its operation suggestion according to the level damage of the crop.

Keywords : expert system, fuzzy inference, knowledge base, max-min method, center average defuzzifier.

Penelitian ini dilakukan berdasarkan atas kebutuhan akan adanya alat bantu bagi petani dalam menentukan hama/penyakit pada tanaman sayuran/palawija serta bagaimana mengendalikannya agar tidak keliru dalam memakai peptisida. Alat bantu tersebut merupakan sistem pakar yang selain untuk mendiagnosis, sistem ini diharapkan mampu memberikan saran-saran pengendalian. Pada dasarnya perangkat lunak ini terdiri atas 2 bagian utama, yaitu bagian input basis pengetahuan, dan bagian konsultasi. Keputusan yang diambil dengan menggunakan metode aturan. Metode inferensi yang digunakan adalah metode inferensi fuzzy dengan defuzzifikasi menggunakan metode max-min dan center average. Keluaran dari perangkat lunak ini adalah jenis hama/penyakit yang menyerang tanaman dan saran pengendaliannya sesuai dengan besar kerusakan yang dialami oleh tanaman tersebut.

Kata kunci : sistem pakar, mesin inferensi fuzzy, basis pengetahuan, metode max-min, center average defuzzifier.
\end{abstract}

\section{Pendahuluan}

Hama dan penyakit senantiasa dijumpai pada setiap tanaman tidaklah asing lagi bagi petani, tetapi masalahnya adalah apakah hama atau penyakit tersebut menimbulkan kerugian yang berarti atau tidak. Kegagalan panen merupakan kendala yang sering dihadapi petani, terutama pada tanaman sayuran/palawija, sebagian besar disebabkan karena tanaman diserang oleh hama dan penyakit. Kadang-kadang petani tahu kalau tanamannya diserang hama/penyakit, tetapi petani tidak tahu hama/penyakit apa yang sedang menyerang tanamannya. Selain itu hal lain yang menyebabkan kegagalan panen adalah karena kesalahan dalam memilih obat yang akan digunakan dan komposisi obat yang digunakan untuk menanggulangi hama/penyakit.

Berdasarkan kemajuan dalam bidang komputer dan informatika, kerumitan dan kesulitan dapat ditanggulangi dengan menyediakan suatu perangkat lunak sistem pakar untuk menentukan hama dan penyakit yang menyerang tanaman sayuran/palawija dan jenis obat serta cara pencegahannya. Salah satu bidang kecerdasan buatan adalah sistem pakar (Expert System) dimana pengetahuan seorang pakar atau beberapa pakar dalam bidang tertentu dituangkan ke dalam program komputer. Sistem fuzzy sebagai suatu bidang kecerdasan buatan juga besar peranannya dalam menangani ketidakpastian yang terjadi dalam sistem pakar.

Penelitian ini bertujuan untuk membangun suatu perangkat lunak sistem pakar tentang menentukan hama dan penyakit tanaman sayuran/palawija (studi kasus tanaman bawang merah) dengan menggunakan mesin inferensi fuzzy.

\section{Tinjauan Pustaka}

Sistem pakar merupakan sistem komputer dasar yang menggabungkan pengetahuan, fakta-fakta dan teknik penelusuran untuk memecahkan masalah yang biasanya memerlukan 
keahlian dari seorang pakar. Secara umum proses yang terjadi di dalam sistem pakar merupakan pengumpulan, representasi dan penyimpanan pengetahuan sistem pakar ke dalam komputer dan selanjutnya pengetahuan diakses oleh pemakai. Menurut Turban(1995), sistem pakar terdiri dari dua bagian pokok, yaitu : lingkungan pengembangan dan lingkungan konsultasi. Komponen-komponen yang ada pada sistem pakar sebagai berikut : subsistem penambahan pengetahuan (akuisisi Pengetahuan), basis pengetahuan (knowledge base), mesin inferensi (inference engine), workplace/blackboard, antarmuka (user interface), subsistem penjelasan (explanation facility) dan perbaikan pengetahuan (knowledge refinement).

Mesin inferensi adalah program komputer yang memberikan metodologi untuk penalaran tentang informasi yang ada dalam basis pengetahuan dan dalam workplace, dan untuk memformulasikan kesimpulan (Turban, 1995). Terdapat dua pendekatan untuk mengontrol inferensi dalam sistem pakar, yaitu pelacakan ke belakang (backward chaining), dan pelacakan ke depan (forward chaining). Kedua metode inferensi tersebut dipengaruhi oleh tiga macam penelusuran, yaitu depth-first search, breadth-first search dan best-first search.

Karena pengetahuan dalam sistem berbasis pengetahuan diperoleh dari sumber kepakaran termasuk didalamnya pakar (human expert), dan banyak pengetahuan pakar yang samar (tidak jelas), maka fakta dan aturan dalam basis pengetahuan mengandung informasi yang tidak jelas (Negoita,1985). Dalam kasus ini, proposisi yang digunakan untuk menyusun aturan-aturan dalam basis pengetahuan dinyatakan sebagai proposisi fuzzy dan proses inferensi dilakukan dengan menggunakan logika fuzzy. Proses ini dinamakan inferensi fuzzy.

Logika fuzzy menggunakan himpunan fuzzy dalam merepresentasikan dan memanipulasi informasi yang samar (tidak jelas) untuk keperluan penarikan kesimpulan. Proses penarikan kesimpulan dengan menggunakan logika fuzzy dinamakan inferensi fuzzy. Sistem berbasis pengetahuan atau sistem berbasis aturan dimana basis pengetahuannya direpresentasikan sebagai sekumpulan aturan produksi yaitu aturan-aturan IF-THEN fuzzy dinamakan sistem fuzzy (Wang,1997). Aturan IF-THEN fuzzy adalah pernyataan IF-THEN dimana beberapa kata-kata dalam pernyataan tersebut ditentukan oleh fungsi keanggotaan. Aturan produksi fuzzy adalah relasi fuzzy antara dua proposisi fuzzy. Aturan tersebut dinyatakan sebagai berikut : $\quad$ IF $<$ proposisi fuzzy 1> THEN $<$ proposisi fuzzy 2>

Proposisi fuzzy adalah proposisi yang memiliki derajat kebenaran yang dinyatakan oleh suatu bilangan dalam interval [0,1], dimana benar dinyatakan oleh nilai 1 dan salah dinyatakan oleh nilai 0 (Klir \& Bo,1995). Premis dari aturan fuzzy dapat memiliki lebih dari satu bagian. Semua bagian dari premis dihitung secara simultan dan diselesaikan untuk sebuah nilai tunggal dengan menggunakan operator fuzzy dalam himpunan fuzzy. Secara khusus, basis aturan fuzzy terdiri dari aturan-aturan IF-THEN fuzzy berikut :

$R_{U}{ }^{(k)}=I F x_{1}$ is $A_{1}{ }^{k}$ and $\ldots$ and $x_{n}$ is $A_{n}{ }^{k}$ THEN $y$ is $B^{k}$

$A_{i}^{k}$ dan $B^{k}$ berturut-turut adalah himpunan fuzzy dalam $U_{i} \subset R$ dan $V \subset R$ ( $U$ dan $V$ adalah domain fisik), $i=1,2, \ldots, n$, dan $x=\left(x_{1}, x_{2}, \ldots, x_{n}\right)^{\top} \in U$ dan $y \in V$ berturut-turut adalah variabel input dan output (linguistik) dari sistem fuzzy.

Menurut Havinga et al (1999), terdapat empat tahap dalam pembangunan sistem fuzzy, yaitu fuzzifikasi, inferensi, komposisi, dan defuzzifikasi. Pada tahap fuzzifikasi, variabel input (crisp) dari sistem fuzzy ditransfer ke dalam himpunan fuzzy untuk dapat digunakan dalam perhitungan nilai kebenaran dari premis pada setiap aturan dalam basis pengetahuan. Inferensi diimplementasikan untuk masing-masing aturan dalam basis pengetahuan. Input untuk proses inferensi adalah nilai yang diberikan oleh premis, dan output adalah suatu himpunan fuzzy. Metode yang biasa digunakan dalam proses inferensi adalah min dan product (Havinga et al ,1999). Komposisi adalah proses dimana himpunan fuzzy yang menyatakan output dari setiap aturan dikombinasikan bersama ke dalam sebuah himpunan fuzzy. Metode komposisi yang umum digunakan adalah max (maximum) dan sum. Input dari proses defuzzifikasi sebagai suatu pemetaan dari himpunan fuzzy $\mathrm{B}^{\mathrm{k}}$ dalam $\mathrm{V} \subset \mathrm{R}$ (yang merupakan output dari inferensi fuzzy) ke titik crisp $\mathrm{y}^{*} \in \mathrm{V}$ (Wang,1997). Terdapat tiga teknik yang paling umum digunakan yaitu center of gravity (centriod) defuzzifier, center average defuzzifier, dan maximum defuzzifier. Metode center average defuzzifier menggunakan nilai pusat (center) dan tingginya (height) dari himpunan fuzzy dalam menentukan nilai crisp hasil. Secara khusus, misalkan $\bar{y}^{k}$ adalah pusat 
dari himpunan fuzzy ke-k dan $w_{k}$ adalah tingginya, center average defuzzifier menentukan $y^{*}$ sebagai

$$
y^{*}=\frac{\sum_{k=1}^{M}-k w_{k}}{\sum_{k=1}^{M} w_{k}}
$$

Variabel input dalam sistem fuzzy dinyatakan dalam nilai crisp. Sebagai gambaran, diberikan dua aturan IF-THEN fuzzy berikut:

Aturan 1: IF $x_{1}$ is $A_{1}{ }^{1}$ and $x_{2}$ is $A_{2}{ }^{1}$ THEN $y$ is $B^{1}$

Aturan 2: IF $x_{1}$ is $A_{1}^{2}$ and $x_{2}$ is $A_{2}^{2}$ THEN $y$ is $B^{2}$

Sistem fuzzy akan menentukan himpunan fuzzy B' untuk input nilai crisp yang diberikan. Untuk input nilai crisp, kesimpulan diperoleh melalui empat tahap yaitu fuzzifikasi, inferensi min, komposisi max, dan defuzzifikasi, seperti diilustrasikan dalam gambar 1.

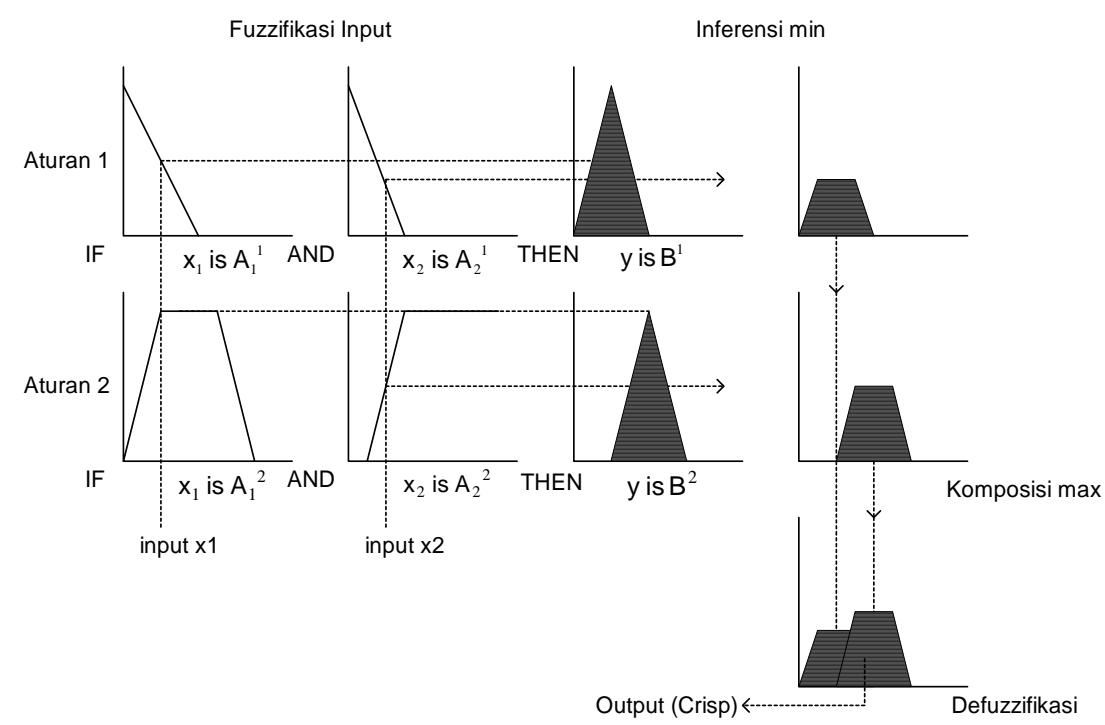

Gambar 1. Penentuan Kesimpulan dalam Sistem Fuzzy Dua Aturan IF-THEN Fuzzy.

\section{Perancangan}

\subsection{Struktur Sistem Pakar}

Struktur sistem pakar untuk menentukan hama/penyakit tanaman dapat dilihat pada Gambar 2.

\subsection{Rancangan Diagram Arus Data (Data Flow Diagram)}

Ada empat proses dalam aplikasi sistem pakar ini yang dapat dilihat pada gambar 3 untuk DAD level 0 dan gambar 4 untuk lebih detailnya.

\subsection{Akuisisi Pengetahuan}

Pengetahuan yang diperoleh meliputi : 1.gejala-gejala; 2.tingkat kerusakan; 3.berat serangan. Pengamatan dilakukan pada tanaman sampel yang tersebar dalam suatu luasan tertentu untuk memperoleh data tingkat kerusakan tanaman. Semua tanaman yang terdapat pada setiap petak sampel diamati. Pengamatan dilakukan pada bagian tanaman dalam rumpun yang bersangkutan.

Berikut kriteria pengambilan sampel : 1.unit sampel: unit sampel sistematik dalam bentuk bagian tanaman; 2.ukuran sampel: jumlah unit sampel tanaman sampel; 3.pola pengambilan sampel : pola sistematik. Yang perlu ditetapkan bila menggunakan pola yaitu : unit sampel, jumlah sampel yang diamati per petak pengamatan dan rute perjalanan pengamat. Rute ini dapat dilakukan sepanjang diagonal petak atau mengikuti baris tanaman selang beberapa baris tertentu dan selanjutnya.

Intensitas berat serangan dilakukan dengan mengamati persentase kerusakan tanaman. Intensitas berat serangan ditentukan berdasarkan persentasi kerusakan tanaman 
pada rumpun tanaman sampel. Kerusakan dihitung berdasarkan jumlah kerusakan bagian tanaman pada seluruh jumlah bagian tanaman dalam tanaman sampel dan dikalikan $100 \%$, kemudian dilakukan perhitungan rata-rata dari masing-masing sampel untuk menentukan nilai intensitas kerusakan yang disebabkan oleh serangan hama/penyakit.

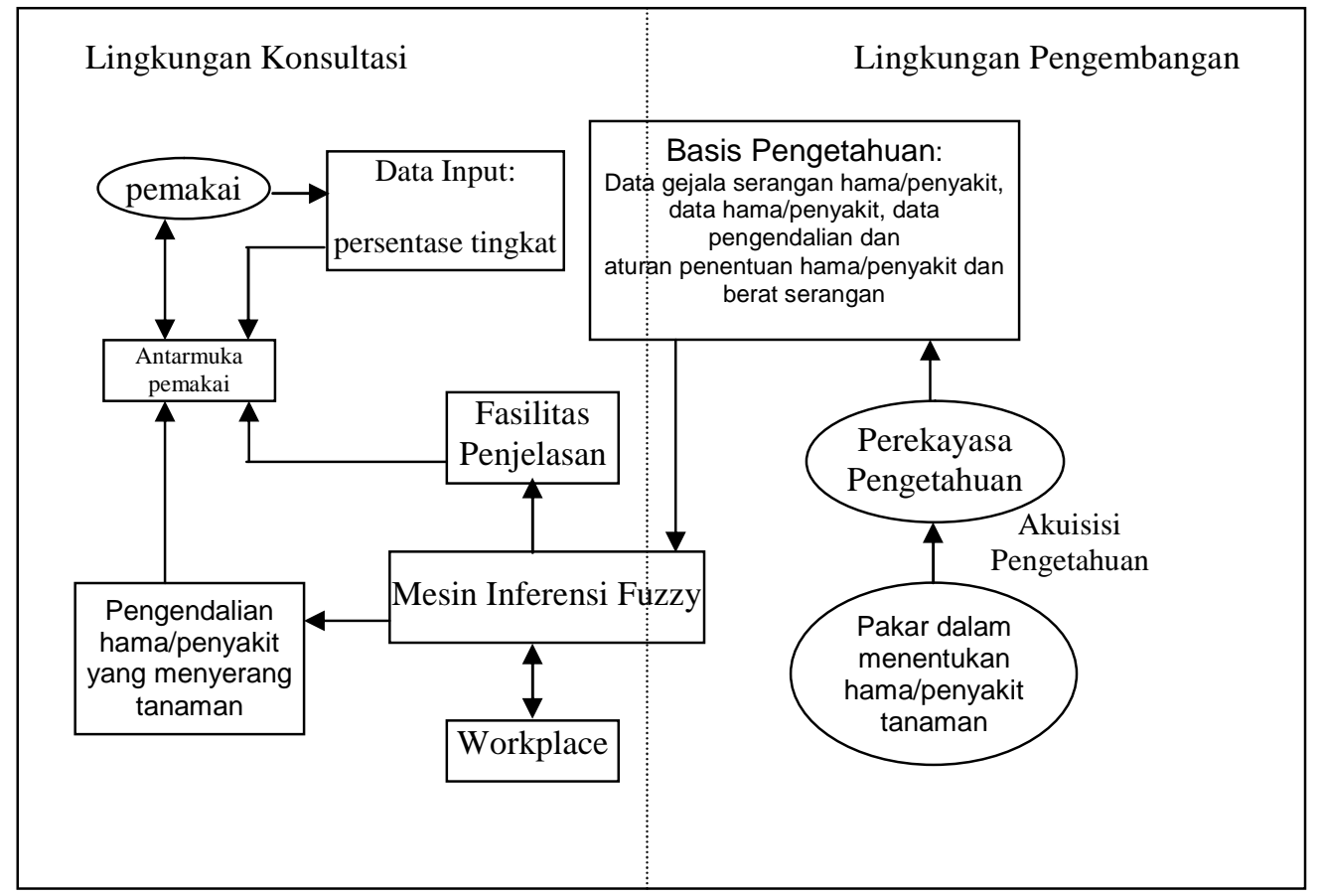

Gambar 2. Struktur Sistem Pakar untuk Menentukan Hama/Penyakit Tanaman.

Dalam program pengendalian hama dan penyakit terpadu, dipakai empat tingkat untuk mengukur berat serangan hama/penyakit (Anonim,1990), yaitu : ringan; sedang; berat; puso. Tingkat kerusakan dibagi menjadi empat tingkat, yaitu : sedikit; sedang; banyak; sangat banyak.

Tabel 1. Tingkat Kerusakan dan Berat Serangan Menggunakan Interval Overlap

\begin{tabular}{|l|l|}
\hline Tingkat Kerusakan & \multicolumn{1}{|c|}{ Interval (\%) } \\
\hline Sedikit & $0-30$ \\
\hline Sedang & $20-55$ \\
\hline Banyak & $45-80$ \\
\hline Sangat banyak & $70-100$ \\
\hline
\end{tabular}

\begin{tabular}{|l|l|}
\hline \multicolumn{1}{|c|}{ Berat Serangan } & \multicolumn{1}{c|}{ Interval (\%) } \\
\hline ringan & $0-30$ \\
\hline sedang & $20-55$ \\
\hline berat & $45-80$ \\
\hline puso & $70-100$ \\
\hline
\end{tabular}

Interval berat serangan dibagi seperti interval tingkat kerusakan, karena memperhatikan bahwa berat serangan hama/penyakit yang menyerang tanaman sebanding dengan nilai kerusakan tanaman (Untung,K,1996).

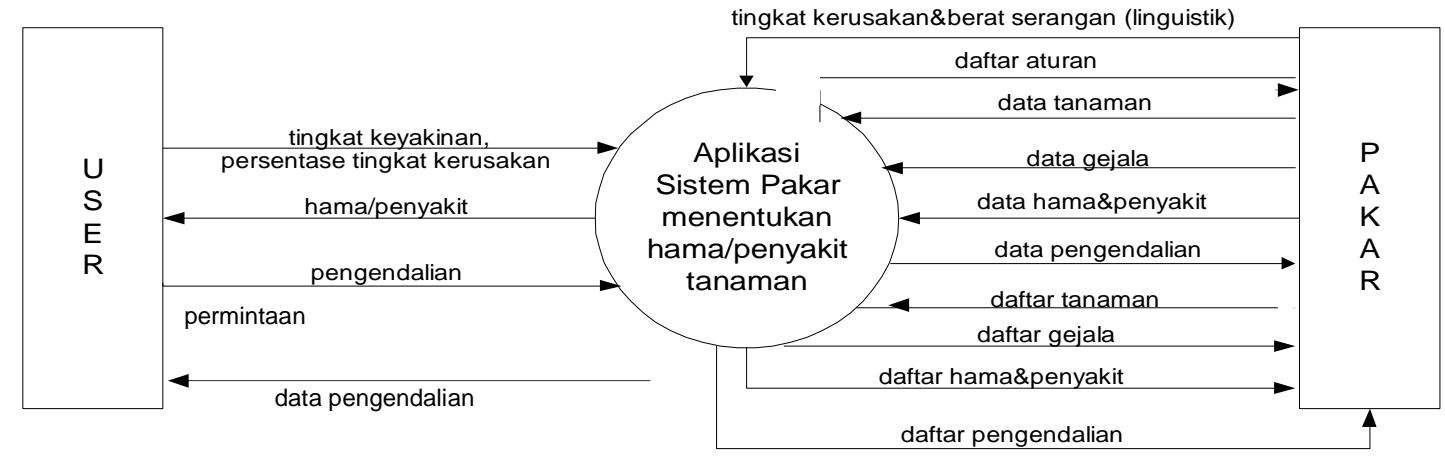

Gambar 3. Diagram Arus Data Level 0 


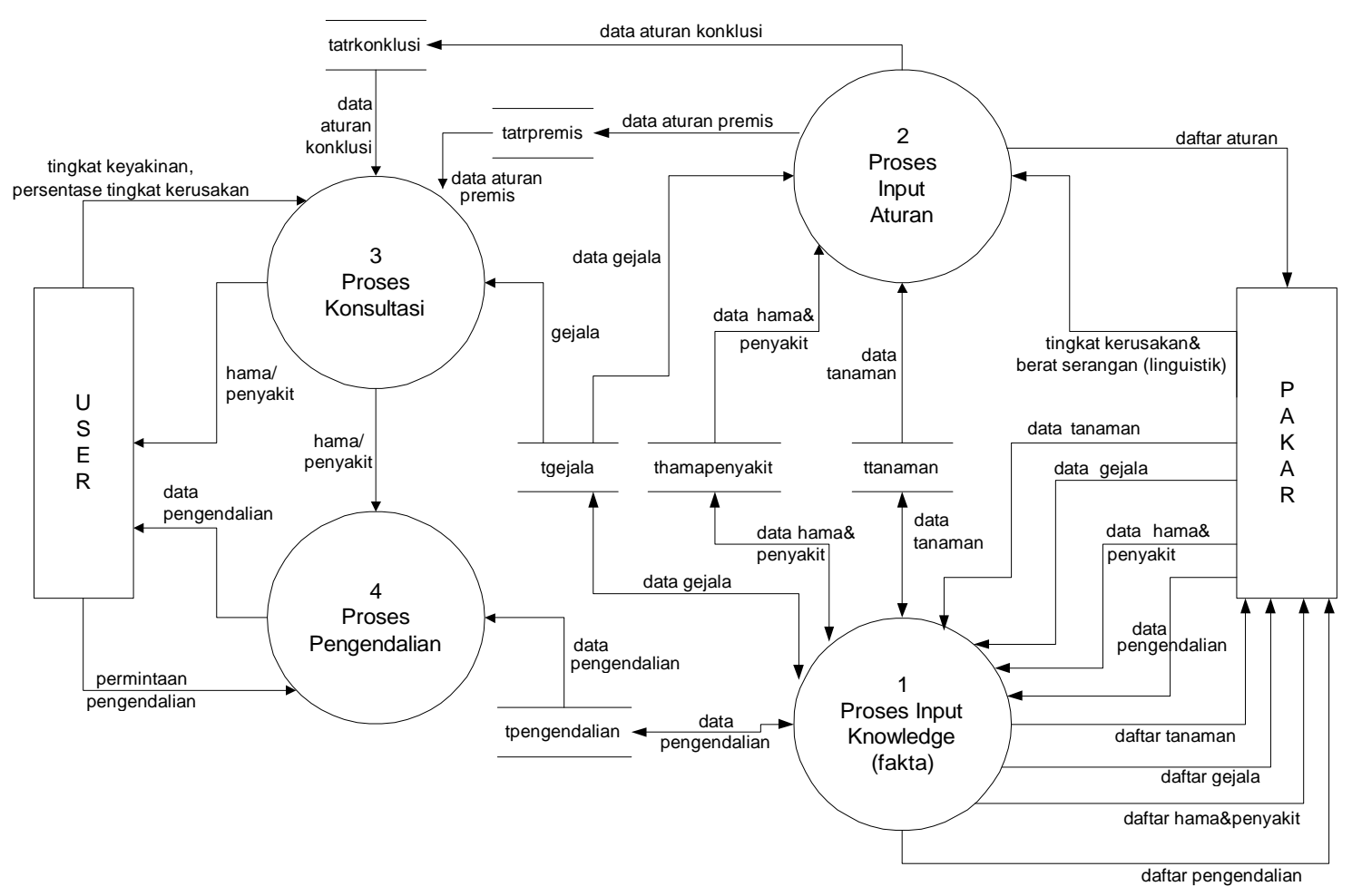

Gambar 4. Diagram Arus Data Level 1

\subsection{Representasi Aturan Fuzzy (Fuzzy Rule Representation)}

Terdapat 84 aturan fuzzy yang terbentuk pada penelitian ini. Tabel 2 berikut contoh representasi aturan fuzzy.

Tabel 2. Contoh Tabel Representasi Aturan

\begin{tabular}{|l|l|c|l|}
\hline Gejala & Tingkat kerusakan & P1 (Penyakit bercak ungu) & Gabungan \\
\hline \multirow{2}{*}{$\begin{array}{l}\text { G1: ujung daun } \\
\text { kering }\end{array}$} & sedikit & - & G1 AND G2 \\
=> P1 & (tabel 3) \\
\cline { 2 - 3 } & sedang & - & \multirow{2}{*}{ G1 AND G3 } \\
\cline { 2 - 3 } & banyak & - \\
\cline { 2 - 3 } & sangatbanyak & - & \\
\hline \multirow{2}{*}{$\begin{array}{l}\text { G2: bercak } \\
\text { berwarna abu- } \\
\text { abu pada daun }\end{array}$} & sedikit & - \\
\cline { 2 - 3 } & sedang & - \\
\cline { 2 - 3 } $\begin{array}{l}\text { G3: bercak cincin } \\
\text { berwarna ungu } \\
\text { dengan tepi } \\
\text { kuning pada } \\
\text { daun }\end{array}$ & sangatbanyak & - \\
\cline { 2 - 3 } & sedikit & - \\
\cline { 2 - 3 } & sanyak & - \\
\hline
\end{tabular}

Tabel 3. Contoh Tabel Representasi Aturan Gabungan

\begin{tabular}{|l|l|l|l|l|l|}
\hline NO & G1 AND G2 => P1 & \multicolumn{4}{|c|}{ G1 } \\
\hline 1 & G2 & sedikit & sedang & banyak & sangat banyak \\
\hline & Sedikit & ringan & ringan & sedang & berat \\
\hline & Sedang & sedang & sedang & berat & berat \\
\hline & Banyak & berat & berat & berat & puso \\
\hline & sangat banyak & puso & puso & puso & puso \\
\hline
\end{tabular}




\subsection{Proses Inferensi (Inference Engine)}

Secara garis besar, diagnosa hama dan penyakit tanaman dengan berat serangannya ditentukan melalui tahap inferensi berdasarkan data input yang dinyatakan sebagai nilai crisp. Proses inferensi dilakukan dengan menggunakan metode pelacakan ke belakang (backward chaining). Terdapat empat tahap dalam penentuan hama dan penyakit dari input nilai crisp berdasarkan inferensi fuzzy, yaitu fuzzifikasi, inferensi, komposisi dan defuzzifikasi. Metode inferensi yang digunakan dalam penelitian ini adalah min, sedangkan metode komposisi yang digunakan adalah max. Kombinasi kedua tersebut sering dikenal sebagai inferensi max-min. Metode defuzzifikasi yang digunakan adalah center average defuzzifier.

\subsection{Fuzzifikasi (Fuzzification)}

Fungsi keanggotaan untuk setiap tingkat kerusakan dan berat serangan adalah berbentuk trapesium dengan domain yang sama yaitu range antara 0 sampai $100 \%$. Gambar 5 memperlihatkan representasi himpunan fuzzy menggunakan fungsi matematika untuk fuzzifikasi. Fungsi keanggotaan untuk gejala tanaman berkaitan dengan tingkat kerusakan ditunjukkan dalam Gambar 6. Fungsi keanggotaan hama/penyakit berkaitan dengan berat serangan sama dengan fungsi keanggotaan gejala tanaman berkaitan dengan tingkat kerusakan dengan variabel linguistiknya ringan, sedang, berat dan puso dengan nilai pusat masing-masing $12.5,37.5,62.5$ dan 87.5 .
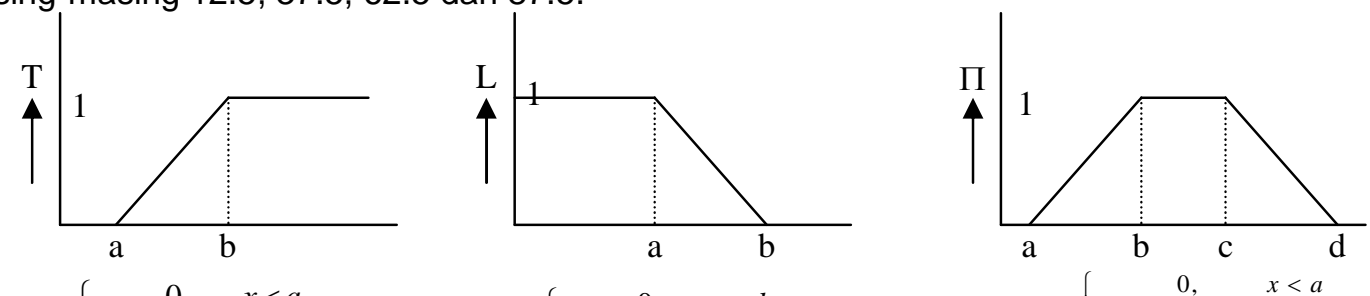

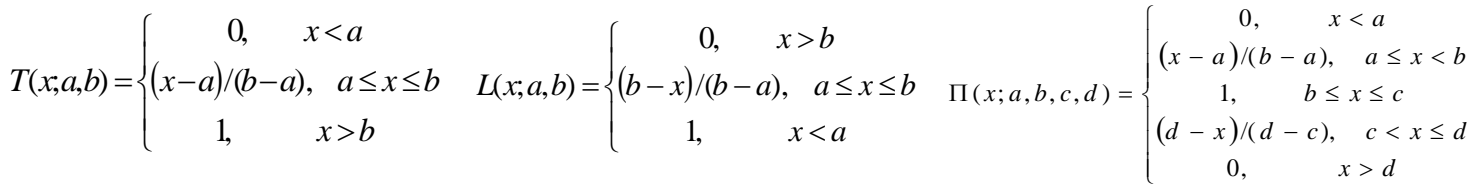

Gambar 5. Fungsi Trapesium

$\mu$

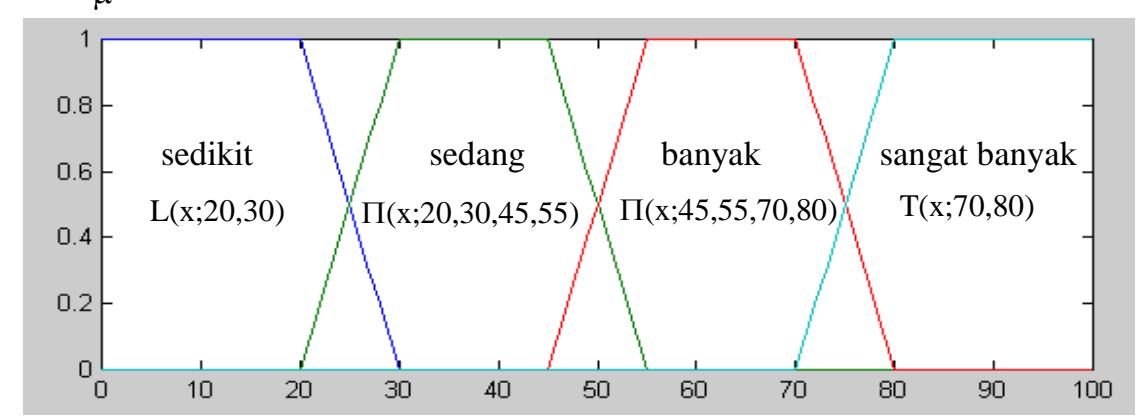

\section{Gambar 6. Fungsi Keanggotaan Gejala Tanaman Berkaitan dengan Tingkat Kerusakan}

\section{Hasil Penelitian}

Hasil keluaran dari sistem pakar ini berupa jenis hama/penyakit dan informasi cara pengendaliannya pada tanaman yang dipilih. Pemakai bisa melakukan konsultasi dengan sistem untuk mengetahui kondisi berdasarkan pengamatan dan pertanyaan-pertanyaan yang harus dijawab oleh pemakai. Pemakai hanya menjawab atau mengklik radiobutton 'ya' atau 'tidak'. Ketika pemakai menjawab 'ya', pemakai harus memasukkan persentase tingkat kerusakan untuk gejala-gejala tertentu. Penelusuran untuk mencapai tujuan sistem akan menampilkan beberapa pertanyaan, jika user menjawab 'ya' berarti kondisi true pelacakan akan dilanjutkan ke node yang paling dalam. Jika user menjawab 'tidak', oleh program menemui jalan buntu maka solusinya adalah melakukan lacak runut balik ke level node diatasnya, kemudian pencarian dilanjutkan ke anak cabang node berikutnya, sampai mencapai kesimpulan. Kesimpulan yang didapat hanya nama hama/penyakit yang menyerang tanaman tersebut, tetapi belum sampai kesimpulan berapa berat serangan hama/penyakitnya. Program akan 
mengambil semua aturan yang mempunyai fakta dan kesimpulan yang sama. Dengan memakai tingkat kerusakan yang diinput pemakai untuk tiap-tiap fakta, dapat dihitung berat serangan hama/penyakit yang menyerang tanaman menggunakan sistem inferensi fuzzy.

\subsection{Contoh Proses dan Hasil Konsultasi}

Data input gejala-gejala hama/penyakit tanaman bawang merah:

a. daun berwarna putih $=$ ya, dengan tingkat kerusakan $=21 \%$

b. daun terkulai $=$ ya , dengan tingkat kerusakan $=24 \%$

Nilai-nilai keanggotaan tersebut adalah :

a. daun berwarna putih (dp)

$$
\begin{aligned}
& \mu_{\text {dPSEDIKIT }}(21)=(30-21) /(30-20)=0.9 \\
& \mu_{\text {dpSEDANG }}(21)=(21-20) /(30-20)=0.1
\end{aligned}
$$

b. daun terkulai (dt)

$$
\begin{aligned}
& \mu_{\text {dtSEDIKIT }}(24)=(30-24) /(30-20)=0.6 \\
& \mu_{\text {dtSEDANG }}(24)=(24-20) /(30-20)=0.4
\end{aligned}
$$

Aturan Fuzzy yang dipicu adalah :

$\mathrm{R} 1$ : If $\mathrm{dp}$ is sedikit and dt is sedikit then hama ulat bawang is ringan

$\mathrm{R} 2$ : If $\mathrm{dp}$ is sedikit and $\mathrm{dt}$ is sedang then hama ulat bawang is ringan

$\mathrm{R} 3$ : If $\mathrm{dp}$ is sedang and $\mathrm{dt}$ is sedikit then hama ulat bawang is sedang

$\mathrm{R} 4$ : If $\mathrm{dp}$ is sedang and $\mathrm{dt}$ is sedang then hama ulat bawang is sedang

Dengan mengaplikasikan operator min diperoleh nilai kebenaran premis :

Premis R1 $: \min \left(\mu_{\text {dPSEDIKIT }}(21), \mu_{\text {dtSEDIKIT }}(24)\right)=\min (0.9,0.6)=0.6$

Premis R2 $: \min \left(\mu_{\text {dPSEDIKIT }}(21), \mu_{\text {dtSEDANG }}(24)\right)=\min (0.9,0.4)=0.4$

Premis R3 $: \min \left(\mu_{\text {dpSEDANG }}(21), \mu_{\text {dtSEDIKIT }}(24)\right)=\min (0.1,0.6)=0.1$

Premis R4 $: \min \left(\mu_{\text {dPSEDANG }}(21), \mu_{\text {ditSEDANG }}(24)\right)=\min (0.1,0.4)=0.1$

Fungsi keanggotaan yang dihasilkan dari proses inferensi adalah sebagai berikut :

$$
\begin{aligned}
& \mu_{\text {Ouput_R1 }}(y)=\left\{\begin{array}{ll}
0.6, & 0<y<24 \\
\frac{30-y}{10}, & 24 \leq y \leq 30 \\
0, & \text { selainnya }
\end{array} \quad \mu_{\text {Ouput }_{2} 2}(y)= \begin{cases}0.4, & 24 \leq y \leq 51 \\
\frac{y-20}{10}, & 20 \leq y<24 \\
\frac{55-y}{10}, & 51<y \leq 55 \\
0, & \text { selainnya }\end{cases} \right. \\
& \mu_{\text {Output_R3 }_{\text {_ }}}(y)=\left\{\begin{array}{ll}
0.1, & 0<y<29 \\
\frac{30-y}{10}, & 29 \leq y \leq 30 \\
0, & \text { selainnya }
\end{array} \quad \mu_{\text {Output }_{-} 4}(y)= \begin{cases}0.1, & 21 \leq y \leq 54 \\
\frac{y-20}{10}, & 20 \leq r<21 \\
\frac{55-y}{10}, & 54<y \leq 55 \\
0, & \text { selainnya }\end{cases} \right.
\end{aligned}
$$

Fungsi keanggotaan dari output yang dihasilkan dari proses komposisi adalah

$$
\mu_{\text {Output }}(y)= \begin{cases}0.6, & 0<y \leq 24 \\ \frac{30-y}{10}, & 24<y \leq 29 \\ 0.1, & 29<y \leq 54 \\ \frac{55-r}{10}, & 54<y \leq 55 \\ 0, & \text { selainnya }\end{cases}
$$

Pusat dari himpunan fuzzy output R1, R2, R3 dan R4 berturut-turut adalah $\bar{y}^{1}=12.5, \bar{y}^{2}=$ $12.5, \bar{y}^{3}=37.5, \bar{y}^{4}=37.5$ dan tingginya berturut-turut adalah $\mathrm{w}_{1}=0.6, \mathrm{w}_{2}=0.4, \mathrm{w}_{3}=0.1, \mathrm{w}_{4}$ 
$=0.1$. Metode center average defuzzifier menentukan berat serangan hama/penyakit $\left(y^{*}\right)$ sebagai berikut :

$$
y^{*}=\frac{12.5 \times 0.6+12.5 \times 0.4+37.5 \times 0.1+37.5 \times 0.1}{0.6+0.4+0.1+0.1}=16.67
$$
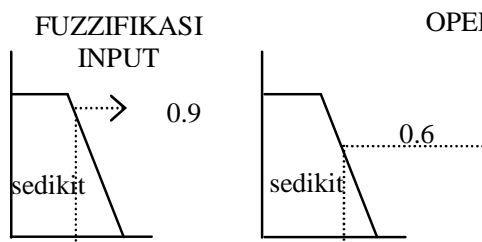

R1 : if dp is sedikit and dt is sedikit then h.ulat bawang is ringan
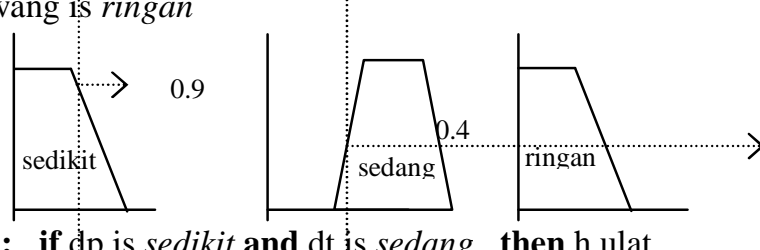

R2 : if $\mathrm{dp}$ is sedikit and dt in sedang then h.ulat bawang is ringan
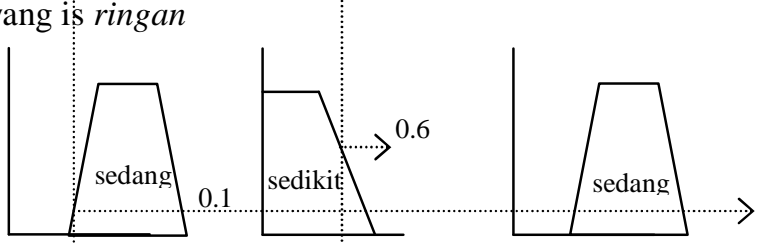

R3 : if $\mathrm{dp}$ is sedang and dtis sedikit then h.ulat bawang is sedang

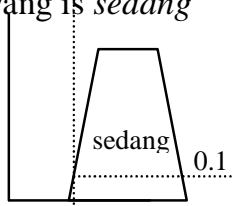

R4 : if $\mathrm{dp}$ is sedang and dit is sedang then h.ulat bawang is sedang

$$
\begin{array}{cc}
\begin{array}{c}
\text { daun berwarna } \\
\text { putih = }=21 \% \\
\text { input 1 }
\end{array} & \begin{array}{c}
\text { daun terkulai } \\
=24 \% \\
\text { input 2 }
\end{array} \\
& y^{*}=16.67
\end{array}
$$
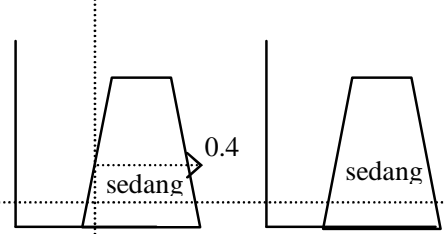

$$
\text { then }
$$

output R4

\section{Gambar 8. Contoh : Proses Inferensi}

output

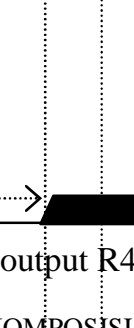

KOMPOSISI MAX

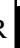
DEFUZZIFIER

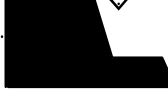
output R1

output R3 output R2
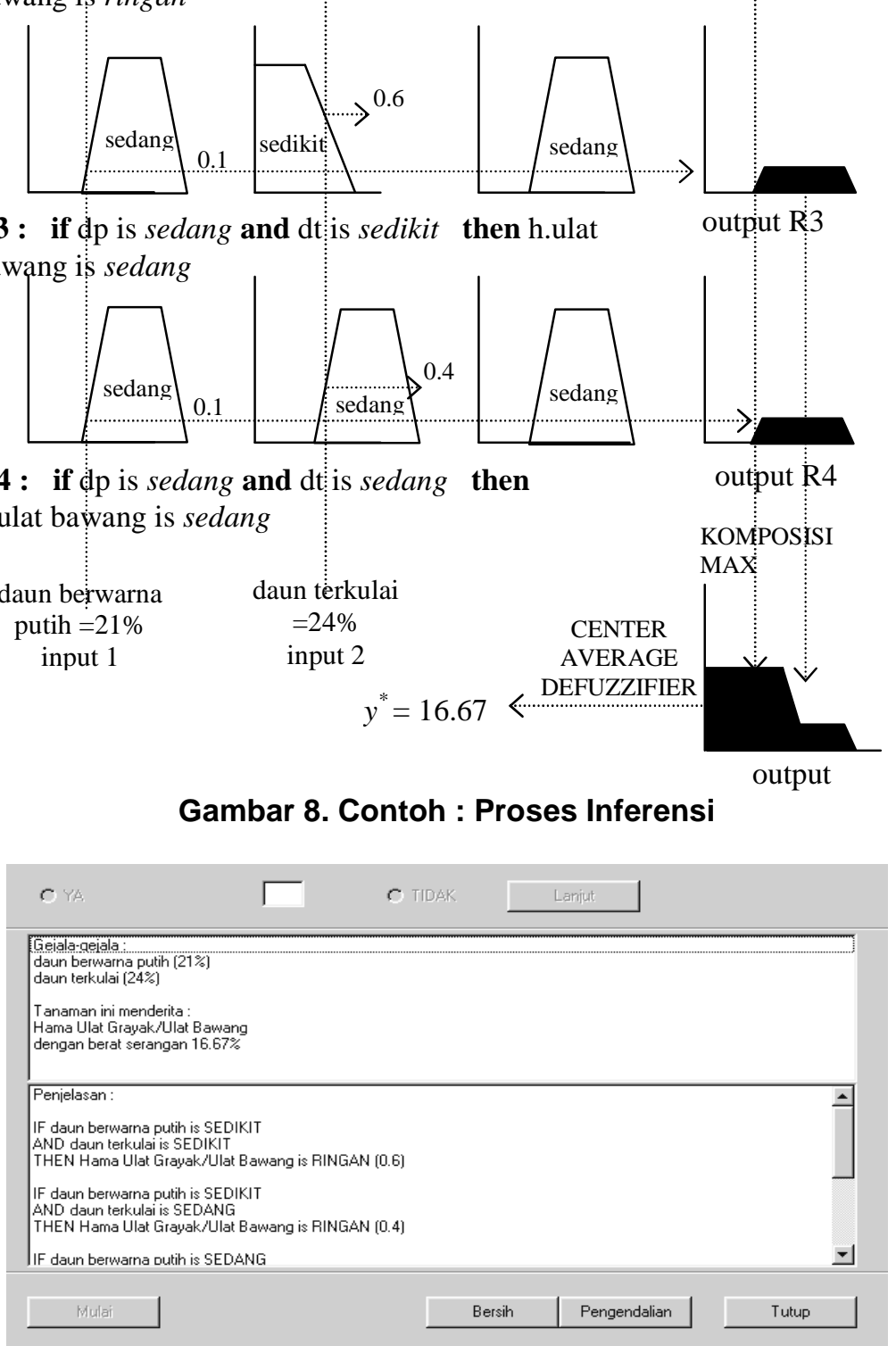

Gambar 9. Contoh : Output 


\section{Kesimpulan}

a. Prototipe perangkat lunak sistem pakar menggunakan mesin inferensi fuzzy yang telah dibangun dapat digunakan untuk menentukan hama dan penyakit pada tanaman sayuran/palawija khususnya tanaman bawang merah.

b. Data input tingkat kerusakan pada gejala tanaman dinyatakan sebagai nilai crisp dan data output berat serangan hama/penyakit pada tanaman juga bernilai crisp.

c. Inferensi fuzzy digunakan untuk menentukan berat serangan hama/penyakit. Berat serangan ini menentukan pengendalian untuk menanggulangi hama/penyakit tersebut.

d. Data tanaman dan gejala terserang hama/penyakit yang digunakan untuk membentuk aturan disimpan dalam file basis data, sehingga data baru dapat ditambahkan ke dalam sistem tanpa mempengaruhi mesin inferensi fuzzy yang telah dibangun.

e. Output dari sistem pakar tersebut berupa jenis hama/penyakit dan berat serangannya, serta dilengkapi dengan cara pengendaliannya. 


\section{Daftar Pustaka}

-, 1990, Pengendalian Hama Terpadu Untuk Tanaman Bawang Merah, Fakultas Pertanian UGM, Yogyakarta.

-, 1992, Hama Penyakit Sayuran Dan Palawija, Penerbit PT. Penebar Swadaya, Anggota IKAPI, Jakarta.

Firebaugh M. W., 1989, Artificial Intelligence. A Knowledge-Based Approach, PWS-Kent Publishing Company, Boston.

Havinga H.N.J, van der Veer P., Brouwer, J. Cser., 1999, Fuzzy Logic, Technical Report. Faculty of Civil Engineering and Geosciences, Delft University of Technology, Netherlands.

Kamal, Raj, \& Saini, H.S., 2002, Web Based Fuzzy Expert System For Integrated Pest Management In Soybean, International Journal of Information Technology, Vol.8, No. 1 August 2002.

Kaswidjanti,W., 2004, Sistem Pakar Menggunakan Mesin Inferensi Fuzzy Untuk Menentukan Hama Dan Penyakit Pada Tanaman Sayuran/Palawija (Studi kasus hama dan penyakit tanaman bawang merah), Tesis, UGM, Yogyakarta.

Klir, G. J \& Y. Bo., 1995, Fuzzy Set and Fuzzy Logic: Theory and Applications. Prentice-Hall International, Inc, New Jersey.

Negoita, C. V., 1985, Expert Systems and Fuzzy Systems. The Benjamin/cummings Publishing Company, Inc. California.

Semangun, Haryono, 2000, Penyakit-Penyakit Tanaman Hortikultura Di Indonesia, Gadjah Mada University Press, Yogyakarta.

Sukaesih,l., 2002, Sistem Berbasis Pengetahuan Untuk Evaluasi Kesesuaian Lahan Untuk Tanaman Budidaya Dengan Mesin Inferensi Fuzzy, Tesis, UGM, Yogyakarta.

Turban, Efraim, 1995, Decision Support System and Expert System, $4^{\text {th }}$ ed., Prentice-Hall, Inc., New Jersey, pp 472-679

Untung, Kasumbogo, 1996, Pengantar Pengelolaan Hama Terpadu, Gadjah Mada University Press, Yogyakarta.

Wang, L. 1997. A Course in Fuzzy Systems and Control. Prentice-Hall International, Inc., New Jersey. 